Nordisk Tidsskrift for Kriminalvidenskab 2010

DEN STRAFFERETLIGE BEHANDLING AF BAGATELAGTIGE SAGER * Af professor Vagn Greve

Zero tolerance has become an influential political ideology. Therefore we have good reasons to reconsider the limits of criminalization, the judicial and administrative interpretation of provisions concerning minor infractions of law, and the sanctions applied to such. The author warns against the development and calls for a renewed respect for Rechtsstaat ideology.**

Moralen her skal kort, dog noget fyndigt gives: Man ei om Bagatel maae med sin Noeste kives Johan Hermann Wessel

\title{
I. INDLEDNING
}

Der var engang, da jeg var ung, og t o l e $\mathrm{r}$ a $\mathrm{n} \mathrm{c}$ e var en positiv egenskab og et kendetegn på humanisme - der dengang ligeledes var en positiv holdning. Lovovertræderne var medmennesker; kriminaliteten var normalitet (Greve 1972); livsytringerne, herunder normafvigelserne, var ikke sort/hvide, men nuancer i gråt (Stangeland \& Hauge 1974); strafanvendelsen burde begrænses. Dengang var vi alle lovovertrædere; nu er vi alle ofre. Nu er in t o 1 e r a n c e blevet en egenskab, som fremholdes med stolthed (Greve 2007), og afvigerne er blevet "de andre" (Greve 2010). Vi ser skiftet på mangfoldige områder - også uden for det strafferetlige - f.eks. i diskussionerne om udlændinge og folkeskolens pædagogik, i rygerexorcismen og nypuritanismen.

Lovgivningen og regeladministrationen afspejler nutidens nultoleranceideologi. Dermed bliver de bagatelagtige normbrud særligt teoretisk og praktisk vigtige. Det er blandt andet nødvendigt at (gen)overveje,

hvilke grænser der bør være for kriminalisering;

- hvilken betydning det har for lovfortolkningen og regelanvendelsen, at lovbruddet har en bagatelagtig karakter;

_ hvilke sanktioner der er og bør være på området.

Dette understreges af, at bagatelagtig kriminalitet på (næsten) alle områder udgør hovedparten af kriminaliteten. Det gælder sågar også den grænseoverskridende kriminalitet, som ellers hyppigt drages frem som særligt farlig. (De seneste

\footnotetext{
Oplæg ved Nordisk Kriminalistmøde 2010. I denne gengivelse er behandlingen af de straffeprocessuelle spørgsmål udeladt.

** Title in English: Minor Cases in Criminal Law. Original in Danish.
} 
danske tal vedrører 2006: $1 \%$ af straffelovsafgørelserne vedrørte udlændinge, der opholdt sig ulovligt her i landet, og $4 \%$ med lovligt ophold (turister/med visum). De største kriminalitetsgrupper for den sidstnævnte kategori var butikstyveri (42 $\%)$, andre tyverier (17\%) og narkotikasmugleri m.m. (10\%)).

\section{KRIMINALISERING}

A. Udsyn

Afvisningen af tolerance er spredt udover kloden. Singapores verdensberømmelse skyldes ikke mindst dens brutale afstraffelser. California og andre u.s.amerikanske delstater afviste proportionalitetsprincippet som grundlaget for samfundets strafudmåling og indførte $25+$ års fængsel for helt bagatelagtig kriminalitet (three strikes and you're out) - også selv om det påviseligt fik drabstallene til at stige kraftigt (Kovandzic et al. 2002). New Yorks politi tilsluttede sig en opfattelse, der anså smadrede ruder og andre bagateller for roden til alskens ondt (Wilson \& Kelling 1982). De først publicerede resultater syntes at vise, at man ved at fjerne bagatellerne kunne hindre det alvorlige. Kriminologer kunne dog hurtigt dokumentere, at udviklingen i New York svarede til udviklingen i andre storbyer, hvor politiet havde fortsat med at prioritere arbejdsindsatsen på andre måder (Holmberg \& Snare 1998; Harcourt \& Ludwig 2006); og at broken-pane-strategien tværtimod havde en mængde uønskede virkninger (Howell 2009). Det stoppede ikke alverdens politikere i at udnytte zero-tolerance, f. eks. i det engelske valg i 1997 og det tyske i 1998. Søren Pind (Venstre) og Københavns Kommune bruger stadig henvisninger til New York som retfærdiggørelse af deres intolerancepolitik (2009); tilsvarende gør Københavns Politi ved ungdomshusuroligheder (Retsudvalgets spm. nr. 946 (Alm. del) 2007-08). I sit indlæg på kriminalistmødet påpegede Dan Frände overbevisende den nære sammenhæng mellem nultoleranceideologien og Feindstrafrechtstankegangen.

I dag er intolerancen en særdeles fremtrædende del af det officielle og private Danmarks erklærede ideologi. Det er imidlertid ikke nok for vore politikere: Pia Allerslev (Venstre) vil have "mere nultolerance" (Pol. 11.11.2009); Søren Pind (Venstre) og Nicolai Wammen (Soc.) ønsker "konsekvent nultolerance" (hhv. Berl.T. 26.3.2008 og valgpropaganda 2009); fødevareminister Eva Kjer Hansen (Venstre) "absolut nultolerance" (Landbrugsavisen 7.9.2009); og i februar 2007 sendte justitsminister Lene Espersen (Kons.) et lovudkast i høring med rubrikken "Skærpet nul-tolerance i fængsler over for blandt andet narko".

Holdningen afhænger dog også - hos alle(?) - af livsområdet; der er langt fra altid konsekvens i denne henseende. Eksempelvis har Lene Espersen, der med hensyn til vold og narkotika krævede nultolerance, som justitsminister vist forståelse for arbejdsgiverne og gennemført en slækkelse af deres ansvar for arbejds- 
miljøkrænkelser og som økonomi- og erhvervsminister beroliget bankdirektørerne med, at Finanstilsynet ikke primært skal se på, om reglerne overholdes (Pol. 6.12.2009).

\section{B. Retspolitikkens grundlag}

In short, the most pressing problem with the criminal law today is that we have too much of it Douglas Husak

Retspolitik afhænger først og fremmest af menneske- og samfunds s y net, meget lidt af den "faktiske virkelighed" - til trods for den hyppige fremhævelse af det kundskabsbaserede. Der er stor forskel på regelværket i en retstat, en social- eller velfærdsstat, en angststat eller en politistat. Det er imidlertid kun retstatsideologien, som direkte betoner det ønskelige i, at lovgivningen begrænses kraftigt. Socialstaten, angststaten og politistaten har-med alle deres forskelle - det fælles, at de gennemfører en minutiøs statsregulering af borgernes adfærd. Medens retstaten bruger straffelovgivningen til at hindre borgerne $\mathrm{i}$ at skade medborgerne, kontrollerer social-, angst- og politistaten livet i dets mindste detaljer. Blot et enkelt eksempel: Dansk Folkeparti har rejst spørgsmål om en lovregulering af undulaters siddepinde (Folketingets Retsudvalg 2009-10 Alm. del nr. 1306). Diskussioner om kriminalisering og strafniveau er dermed helt afhængige af, om deltagerne har en retstatsideologi eller en af de andre samfundsideologier. Jeg bekender mig til en retstatsideologi, og derfor tager jeg, som det vil fremgå af det følgende, afstand fra den eksisterende og stadigt voksende detailstyring af borgerne og samfundet. Det er ikke blot, når man er in dubio, at man bør være pro libertate.

I nordisk teori har man $\mathrm{i}$ de senere år interesseret sig meget for $\mathrm{a} \mathrm{b} \mathrm{s} \mathrm{r}$ a k te faredelikter, præventive for s krifter og grænserne for f o r s ø g s og m e d virken s strafbarhed. (Se f.eks. Husabø 1999, Asp 2005 og 2007, Langsted 2007 s. 246 ff., Cornils 2008 samt Toftegaard Nielsen 2008 s. 206 ff.). I denne sammenhæng drøfter jeg kun kriminaliseringer, som er begrundet i retsbruddet i sig selv, ikke dem, der har karakter af fremskudt beskyttelse af væsentlige interesser. Også selv om det blankt erkendes, at denne distinktion kan være vanskelig at gennemføre. Præventive forskrifter og abstrakte faredelikter kan med en for udstrakt velvilje næsten alle konstrueres som beskyttende liv og ejendom. Og "[e]in behauptetes Rechtsgut des öffentlichen Friedens ist zudem so ungenau, dass es einen nahezu unbegrenzten Anwendungsbereich für eine Bestrafung eröffnet" (von Hirsch 2005 s. 112).

Medens $\mathrm{p} \mathrm{o} \mathrm{l} \mathrm{i} \mathrm{t} \mathrm{i} \mathrm{s} \mathrm{t} \mathrm{r} \mathrm{a} \mathrm{f} \mathrm{f} \mathrm{e} \mathrm{r} \mathrm{e} \mathrm{t} \mathrm{t} \mathrm{e} \mathrm{n} \mathrm{i} \mathrm{Danmark} \mathrm{i} \mathrm{en} \mathrm{årrække} \mathrm{har} \mathrm{været}$ 
nært knyttet til den egentlige strafferet, ser vi i disse år dens glidning bort fra den egentlige strafferet og over mod forvaltningsstrafferetten og tilsvarende en orientering i forvaltnings strafferetten mod forvaltningsretten. Denne udvikling har - fra en strafferetlig synsvinkel - karakter af en "prostituering", der fører til opgivelse af helt centrale strafferetlige og retstatslige principper. "[D]ie Schlüsselbegriffe heißen nicht mehr unbestimmter Rechtsbegriff, Ermessen oder Verhältnismäßigkeit, sondern Implementierbarkeit, Effizienz oder Regulierung ... "(Volkman 2009 s. 217).

\section{Kriminaliseringsprincipper}

Det, som hverken skader troen eller den almindelige fred og rolighed, det skal vi blot lade løbe gennem solden med de store huller

Peder Palladius

Der findes en række strafferetlige, retsfilosofiske og retspolitiske studier af kriminaliseringens $1 \mathrm{e} g$ i t i m i t e t. (Se f.eks. Jareborg 1995/2002, Lernestedt 2003 og Husak 2008). Mange af dem tager udgangspunkt i den kendsgerning - eller skal man sige opfattelse? - at de fleste lande har et alvorligt samfundsproblem på grund af overcriminalization, som fører til en urimelig stor mængde straf. Studierne har anvendt forskellige indfaldsvinkler og antaget forskellige grundprincipper - herunder retstatslig minimalisme, utilitarisme, andre former for etik samt law \& economics. De er ofte spændende og tankevækkende. I nyere tid synes langt de fleste politikere dog ganske uinteresserede i principielle overvejelser. "The main determinants of criminalization continue to be political opportunism and power ... “ (Ashworth 2009 s. 39). De videnskabelige studier bliver derfor let til l'art pour l'art. Det bør på ingen måde afholde os fra at gennemføre dem; tværtimod er de meget vigtige for strafferetsvidenskaben; og vi bør heller ikke opgive håbet om en fremtidig erkendelse blandt magthaverne af vigtigheden af de fundamentale principper. Det følgende koncentrerer sig dog om andre spørgsmål.

\section{Særligt om ultima ratio}

[D]er er ingen Sot, som i Langden sikrere ruinerer et Folks hele Rets- og Samfundsfølelse end den stundesløse Lovsyge Viggo Hørup

Selv om en interesse er beskyttelsesværdig, er det ikke dermed givet, at den bør værnes gennem straffesystemet. Traditionelt har man man inden for strafferetten gjort gældende, at straf kun bør anvendes, når der ikke er andre sanktioner, som kan 
anvendes. Straf skal være - siges det - det sidste middel ( $u$ l t i m a r a t i o ). Det betyder, at den eksisterende strafferet skal begrænses (af- og nedkriminalisering), og at man bør være tilbageholdende med at nykriminalisere og opkriminalisere.

Ultima-ratio-princippet er blandt andet begrundet i det almindelige $\mathrm{p} \mathrm{r}$ op o r t i o n a lit e t s p r i n c i p, hvorefter der altid skal anvendes den mindst byrdefulde af flere mulige reaktioner. Det gælder såvel inden for strafferetten som i forholdet mellem strafferetten og de øvrige juridiske discipliner. Civilretlige reaktioner, f.eks. pålæggelse af erstatning (hvor der ikke er forsikringsdækning), eller forvaltningsretlige sanktioner, f.eks. inddragelse af en tilladelse til udøvelse af næring, føles formentlig i mange - langt de fleste? - tilfælde væsentligt hårdere end en strafferetlig bøde. Det er derfor et svagt argument for at begrænse kriminaliseringerne.

Traditionelt bliver princippet om ultima ratio - også derfor - helt eller delvis begrundet i de strafferetlige indgrebs særlige karakter. Se Nils Jareborg (2003/2006), der betegnende nok kun diskuterer fængselsstraffen "[f]ör att göra diskussionen meningsfull", idet han i øvrigt - med henvisning til Koskinen og Zila - udtrykker ønske om et system, hvor alle forseelser "har gallrats bort från straffrätten" (2003 s. 94 f., 2006 s. 35). Det er på mange måder forståeligt; det gør det blandt andet meget lettere at tænke principielt. Men en sådan "renset strafferet" har som konsekvens, at borgernes retssikkerhed mindskes betragteligt; udviklingen af det svenske afgiftssystem viser klart denne risiko (Nelson 2004). Tankens renhed og ubesværethed er næppe den pris værd.

Som nævnt er dén traditionelle opfattelse, at strafferetlige reaktioner an sich føles mere belastende end de civilretlige og forvaltningsretlige, klart ikke holdbar. Og det gør det tvivlsomt, om man på trods af dette med baggrund i straffenes "natur" kan hævde, at netop de strafferetlige alligevel skal være ultima. Hvis man antager, at det er en "menneskeret" ikke at blive straffet, kan man imidlertid nå til, "that the decision to criminalize ... should be recognized as being of a different order from many other legislative decisions", f.eks. beskatning (Ashworth $2009 \mathrm{~s}$. 32).

Ultima-ratio-synspunkterne har teoretisk betydning, men de genfindes meget sjældent i lovgivernes diskussioner. I nyere lovgivningspraksis er tendensen klart, at straf uden videre vælges som samfundsindgrebet. Straffen er, set fra politikernes side, den mest bekvemme og billigste form for social kontrol og den mest velegnede "valgpropaganda". Hver dag sin kriminalisering - med Douglas Husak (2008 s. 36): "a crime du jour". Med de ofte meget strenge straffe, som dekreteres, er der hyppigt tale om en stærkt kritisabel mangel på respekt for borgerne, som bruges og opofres som politiske midler. 


\section{LOVFORTOLKNING OG REGELANVENDELSE}

Billighed er Rettens Liv og Siæl

C.D. Hedegaard

Nutidens lovgivning er, som nævnt, i vidt omfang baseret på en nultoleranceideologi. Det rejser naturligvis spørgsmålet om, hvorvidt denne ideologi binder lovanvenderne.

\section{A. Sammenhængen mellem lovgivningsprincipper og retsanvendelsesprin- cipper}

Alle ord og alle formuleringer har u s k a r p e a f g r æ n s n in ge r. Den udvikling, som måske kan konstateres i retspraksis - i dansk som i menneskeretlig - i retning af en større hensyntagen til, om bestemmelsen er formuleret så klart, at borgeren med rimelighed kan finde ud af, hvor grænsen til det strafbare er, gælder uanset lovgivers krav om nultolerance. F o r t o l kn in g s p r o c e s s e $\mathrm{n}$ er principielt den samme, hvad enten man har en streng eller en mild lovgiver. Grundlaget for fortolkningen er blot en anden bestemmelse, end man ville have haft med en mindre rigorøs lovgiver. En nultoleranceideologi bag kriminaliseringsprocessen betyder ikke, at den juridiske tolkning af ord og bestemmelser derfor $\mathrm{s} \mathrm{k}$ a 1 anvende den strengest mulige forståelse af ordene og bestemmelserne, in dubio severissimus; lige så lidt som vi s k u $11 \mathrm{e}$ have anvendt den mildeste, in dubio mitius, hvis lovgivningsmagten havde været tolerant.

De eksisterende spørgsmål kan illustreres af to eksempler:

Efter færdselslovens $\S 4$ skal trafikanter efterkomme de anvisninger for færdslen, som gives ved $\mathrm{f} æ \mathrm{rd} \mathrm{s}$ e $1 \mathrm{~s}$ t a v l e r . Det betyder bl.a., at man skal have nedsat sin hastighed til $50 \mathrm{~km} / \mathrm{t}$, når man når til et byzoneskilt. Mangfoldige steder er der en snes meter efter byzoneskiltet et $60 \mathrm{~km} / \mathrm{t}$-skilt. Ingen vil kunne forestille sig, at gennemkørselen af de $20 \mathrm{~m}$ med $60 \mathrm{~km} / \mathrm{t}$ er en lovovertrædelse - ikke engang selv om den oftest begås med hensigt. Hvorfor ikke?

Omvendt antager det danske Justitsministerium, at en person, der $\mathrm{t} \mathrm{r}$ k k e r en m o t o r c y k e l, jfr. færdselslovens $\S 11$ e c., skal have kørekort til motorcykel, jfr. § 56, og bære fastspændt styrthjelm, jfr. § 81. Hvorfor?

Man mindes den norske højesteretsdom, der fastslog, at det var strafbart at trække sin cykel hjem uden lygte, medens det ville have været lovligt at bære den hjem. (NRt $1948.302 \mathrm{H}$ ).

Der er heldigvis ingen tvivl om, at $\mathrm{sund}$ f o r n u f t også er en retskilde. (Det kan måske operationaliseres som, at et flertal i befolkningen - uden for juristernes kreds - vil have den opfattelse, at der er noget pjat, som myndighederne 
ikke skal spilde deres tid med). Det er kun d å r 1 i g e j u r i s t e r, der tror, at en lovfortolkning kan og skal ske alene ud fra bestemmelsens ordlyd.

\section{B. Eksempler}

En indskrænkende, fornuftig brug af drakoniske regler bliver også - i hvert fald til tider - accepteret af lovgiverne.

I forbindelse med gennemførelse af nye ter r or b e s t e m m e l s e r i straffeloven blev det fra mange sider kritiseret, at 'terror' ikke blev defineret. Justitsministeren forsvarede sig med, at anklagemyndigheden ville bruge bestemmelserne med fornuft og undlade påtale selv i tilfælde, hvor det pågældende forhold ikke kunne bortfortolkes som 'materielt atypisk' (svar på Retsudvalgets spm. nr. 97, L 217 2005-06 (2.)). Og der kan jo ikke være nogen tvivl om, at lovgivningsmagten på dette område ønskede at markere en særdeles klar nultolerance.

Et andet eksempel findes i $\mathrm{kn}$ i v l ovg i v n i n g e n . Efter et modbydeligt drab på en turist krævede Enhedslisten totalforbud mod knive på offentligt sted. (Inf. 7.10.2003). Der var hvert år ca. 35 tilfælde af vold med lovlige knive, d.v.s. almindelige foldeknive med et blad under $7 \mathrm{~cm}$. (Pol. 7.11.2003). Man er nok ganske optimistisk, hvis man tror, at et forbud vil påvirke denne type knivbærere, men justitsministeren fulgte op på forslaget. Det løb dog ind i en massiv modstand fra befolkningen, der af mange gode grunde har en kniv i lommen eller i handskerummet. "Kompromiset" blev, at besiddelse af ganske korte foldeknive på offentligt sted blev tilladt, men at besiddelse af alle andre skulle udløse en ubetinget frihedsstraf. I min familie har vi altid haft en kniv i handskerummet, så vi kunne spise en skive brød med ost og pølse på grøftekanten, når vi kørte gennem Danmark. Nordsjællands Politi fortolker reglerne således, at man godt må have en bord- eller brødkniv med, hvis man har maden til en skovtur med hjemmefra, men ikke, hvis man stopper undervejs og køber maden (Pol. 20.12.2009). Justitsministeriet mener dog, at campere godt må medbringe bestikknive, brødknive og urteknive (svar til Folketingets Retsudvalg 2009-10 Alm. del nr. 799). Overtrædelser skal efter Folketingets opfattelse straffes med ubetinget frihedsstraf. Med Husak (2008 s. 162): Pålæggelse af ansvar for at hindre en så "insubstantial risk" fører til straf for "individuals who are even less culpable than those who are negligent, and codes should rarely if ever impose liability on persons with so little culpability".

Politi og anklagemyndighed tog bestemmelserne på ordet. Da politikerne gennem mediernes beskrivelser af nogle konkrete sager indså, hvad de havde vedtaget, forsvarede de sig med, at retsvæsenet måtte bruge reglerne med omtanke. Om dette skrev rigsadvokaten: "Der har bestemt været sager imellem, hvor det efter anklagemyndighedens (og formentlig også domstolenes) opfattelse kan anses for diskutabelt, om der egentlig er rimelighed i straffen, men hvor det ikke desto min- 
dre har været det, som man mente at måtte udlede af lovgivningen. Og det er som bekendt ikke anklagemyndighedens opgave at sætte egen opfattelse af rimelighed over lovgivningsmagtens.” (Sørensen 2009). Men han mente åbenbart, at Højesteret ikke er undergivet en tilsvarende begrænsning; og det viste Højesteret sig enig i (UfR 2010.789 og 796 H). Højesteret udvidede med sine domme bødemuligheden i forhold til det, som naturligt kunne læses ud af lovforslagets bemærkninger. "[D]ommene synes at være blevet modtaget med velvilje - og måske også en vis lettelse - blandt de partier i Folketinget, som står bag lovgivningen" (Sørensen 2010 s. 62). Det er dog ikke udtryk for, at systemet nu - efter min opfattelse - opfylder elementære rimelighedskrav.

T kørte kl. 13.55 på en landevej. Politiet fandt i bilen en foldekniv på 7,3 $\mathrm{cm}$, hvor klingen kunne låses fast. T oplyste, at han senere samme dag skulle ud i naturen og spise med sin familie. Byretten idømte 7 dages ubetinget fængsel; landsretten en bøde på $3.000 \mathrm{kr}$. (ØL 26.4.2010).

En norsk turist på vej fra Nederlandene til Norge blev kontrolleret af toldvæsenet ved den tysk-danske grænse. Han havde en foldekniv i handskerummet. Bøde på 3.000 kr. Justitsministeren udtalte om sagen: "Det er den enkeltes eget ansvar at gøre sig bekendt med de danske love og regler ..." (Folketingets Retsudvalg spm. 1356 (Alm. del) 2009-10). Det havde dog været nærliggende at give strafbortfald på grund af undskyldelig retsvildfarelse.

\section{En lovfæstet fortolkningsregel?}

Der er mange eksempler på, at danske myndigheder til tider strafforfølger revl og krat. Nogle af sagerne afsluttes med en advarsel. Det kan være en pragmatisk løsning, men den overflødiggør ikke spørgsmålet, om vi burde have en regel svarende til den, som tidligere fandtes i den ø s t r i g s k e Strafgesetzbuch $\S 42$, hvorefter der skulle frifindes, "wenn ... die Tat keine oder nur unbedeutende Folgen nach sich gezogen hat ...". En tilsvarende regel findes i den østrigske Verwaltungsstrafgesetz $\S 21$, stk. 2: "wenn das Verschulden ... geringfügig ist und die Folgen der Übertretung unbedeutend sind". $\S 42$ blev indført dels for at befri myndighederne for arbejdet med bagatelsagerne, dels for at undgå stemplingen af borgerne. Man ville undgå et Volk von Vorbestraften (Nowakowski 1985 s. 529). Bestemmelsen mistede sin betydning i praksis, da man anerkendte et opportunitetsprincip (Priebe 2005 s. 172). Tilsvarende bestemmelser ses så forskellige steder som i U S A s Model Penal Code (1962) art. 2.12.2 og U S S R s straffelov (1961) art. 7, stk. 2.

I T y s k l a n d er der i retspraksis opstillet en almindelig sætning, hvorefter eksempelvis "[w]er den Zugriff ... nur in ganz unerhebliches Maße erschwert, erfüllt nicht den Tatbestand" (Ostendorf 1982). 
I d a n s k ret opnås der på visse områder tilsvarende resultater gennem fastlæggelsen af grænsen for strafbarhed, f.eks. ved vold, blufærdighedskrænkelse og bestikkelse, men det gælder langt fra overalt. Dertil kommer, at visse straffebestemmelser udtrykkeligt er begrænset til grovere forhold, jfr. f.eks. strl. § 296 ("påvirkes væsentligt"). På den anden side har vi udtrykkelige kriminaliseringer af "noget, som er uden betydning" (strl. § 158, stk. 3). (Justitsministerens departementschef synes i en udtalelse til medierne i 2010 at forudsætte, at dette ikke gælder ved § 163). Der er absurde domme med straffe for utjenlige forsøg (f.eks. for tyveri af snavset vand, UfR 1973.648 H). Med Carl Torp kan udvidelsen af tyveribegrebet til at omfatte tilegnelse af værdiløse ting anses for "meget utilfredsstillende, for ikke at sige stødende" (1909 s. 37).

Alment gælder det også her, som det er blevet sagt om I t a 1 i e n , at myndighederne i strid med "der gesunde Menschenverstand" til tider beskæftiger sig med "der Diebstahl völlig wertloser ... Sachen; eine so grobe ... Urkundenverfälschung, dass niemand davon getäuscht wird, ... die falsche Anschuldigung, die so abwegig ist, dass sie Naturgesetzen widerspräche, gegen jede Logik verstieße ..." (Vinciguerra 2008 s. 110 f.).

Der kan argumenteres for, at en regel som den østrigske ville kunne fremme den sunde fornufts indflydelse. Enhedslisten har foreslået, at færdselsloven skulle have en bemyndigelsesbestemmelse, hvorefter det kunne fastsættes, "at overtrædelser, der har karakter af bagateller eller ikke udgør nogen risiko for færdselssikkerheden, ikke straffes" (Retsudvalgets betænkning over L 87 2008-09)), men forslaget fik kun støtte af Socialdemokraterne og Det Radikale Venstre. Hvis man skal kunne forsvare at straffe ligegyldigheder, må det retspolitisk set som det mindste forudsættes, at den subjektive dadelværdighed er stor, d.v.s. forsæt (Greve 1983), men det er der næppe stemning for at kræve.

\section{SARLIGE SANKTIONER}

Øvrighed straffer, som en Fader Barnet, paa det Sted det giør mindst ondt

\section{A. Advarsel}

C.D. Hedegaard

Der findes en række strafferetlige sanktioner - fra strafbortfald, tiltalefrafald og små bøder til langvarige frihedsstraffe. I Danmark kan domstolene endvidere afslutte sagen med en 'advarsel' (rpl. § 900). Den anvendes i praksis så sjældent, at den antager karakter af ikke blot at være en næse til lovovertræderen, men også til anklagemyndigheden for urimelig tiltalerejsning. Hans Gammeltoft-Hansen (1996 s. 60) udtrykker det mere urbant, når han finder årsagen til den relativt sjældne brug af advarslen $i$, at sådanne forseelser normalt afgøres med tiltalefra- 
fald og derfor aldrig når frem til indenretslig behandling. Der kan dog også være andre årsager: f.eks. kan en sag smuldre bevismæssigt under domsforhandlingen, så den i praksis ellers ville være blevet afsluttet med et tiltalefrafald.

Advarslens retlige karakter har været diskuteret; reelt er det den mildeste indenretslige sanktion. Som jeg tidligere (2004) har gjort gældende, burde den flyttes fra retsplejeloven til straffeloven som $\S 55 \mathrm{a}$, i en lettere revideret form, f.eks. som: "Finder retten det på grund af forseelsens karakter upåkravet at idømme frihedsstraf eller bøde, kan den slutte sagen ved at tilføre retsbogen en irettescttelse."

Som eksempler kan nævnes:

Færinger bosat i Hirtshals modtog gratis i overensstemmelse med oldgamle fordelingsprincipper $450 \mathrm{~kg}$ grindehvalkød fra deres hjemø. De havde ikke fået tilladelse hertil fra Skov- og Naturstyrelsen. Retten udtalte, at "der fra de allerførste politiafhøringer ikke har været tvivl hos de personer, der har været i direkte kontakt med de tiltalte, om ..., at de ikke havde nogen anelse om, at der kunne være noget ulovligt i deres handlemåde, der var i fuld overensstemmelse med den ældgamle kultur, de tilhører inden for det danske rigsfællesskab”. Sagen afgjordes ved, "at de tiltalte begge tildeles en advarsel om ikke oftere at overtræde de omhandlede bestemmelser, så længe som de måtte være gældende. Det bemærkes i den forbindelse, at anklagemyndigheden under sagen har tilkendegivet, at det også vil være en overtrædelse af reglerne, hvis færøske kuttere fisker i dansk søterritorium med grindekød om bord som proviant, selv om kutterne ikke anløber dansk havn". (Utrykt afgørelse af 4.6.1991, Retten i Hjørring).

T havde siden 1970 uden problemer drevet en restaurant med de nødvendige bevillinger. Bevillingerne udstedtes for 8 år ad gangen. I 1998 omdannedes virksomheden fra personligt ejet virksomhed til anpartsselskab med T som eneanpartshaver. Da bevillingen tre år senere skulle fornys, gjorde politiet $\mathrm{T}$ opmærksom på, at det var selskabet, som skulle have bevillingen. Den udstedtes uden videre. Derefter udfærdigedes et bødeforelæg på $5.000 \mathrm{kr}$. for virksomhedens manglende bevilling i de tre år. T betalte ikke og blev tiltalt. Dommeren tildelte T en advarsel. (Utrykt afgørelse af 6.2.2003, Retten i Helsinge).

\section{B. Udvisning}

I dansk ret findes de groveste brud på proportionalitetsprincippet på udlændingeområdet - og på narkotikaområdet. Se således vedrørende $\mathrm{u} \mathrm{d} \mathrm{v} \mathrm{i} \mathrm{s} \mathrm{n} \mathrm{i} \mathrm{n} \mathrm{g} \mathrm{:}$

T kom som 4-5-årig til Danmark, hvor forældre og søskende boede. 19 år efter solgte han $0,11 \mathrm{~g}$ heroin. Byretten og landsretten fulgte Folketingets intentioner 
og udviste. Højesteret underkendte loven under henvisning til menneskerettighederne. (UfR 1999.271 H).

T kom til Danmark som 10-årig. Han havde hustru, forældre og søskende her. 23 år efter dømt for besiddelse med henblik på overdragelse af 5,02 g heroin, 4,98 g kokain og 3 rohypnoltabletter. Udvist af landsretten, men ikke af Højesteret, der også her anvendte menneskeretskonventionen. (UfR 1999.1394 H).

Efter 13 års ophold her i landet idømt 14 dages hæfte for besiddelse af 0,18 $\mathrm{g}$ heroin og udvist af byret og landsret, men reddet af Højesteret. (UfR 2000.293 H).

For nylig har man udvist en gruppe rumænske romaer. Udvisningen blev begrundet med deres kriminalitet. De havde camperet på Amager Fælled uden tilladelse! Det siges, at det kan forventes, at EUs kontor for romaer vil anlægge sag mod den danske stat for at få udvisningen underkendt.

Se også følgende afgørelser fra andre dele af u d l æ n d in g e o m råd e t :

En privatperson havde $i$ et halvt år haft en udlænding uden opholds- og arbejdstilladelse som rengøringshjælp tre timer om ugen. Efter lovens forarbejder skulle hun straffes med en bøde på $120.000 \mathrm{kr}$. I byretten blev den $30.000 \mathrm{kr}$., i landsretten $60.000 \mathrm{kr}$. (med dissens for $120.000 \mathrm{kr}$.). Højesteret nåede til 40.000 kr., eftersom "en situation som den foreliggende med et meget begrænset ... timetal, ville føre til en uforholdsmæssig høj bødestraf'. Hvad Højesteret åbenbart ikke mener, at $40.000 \mathrm{kr}$. med en forvandlingsstraf på 20 dages fængsel er. (UfR $2010.549 \mathrm{H})$.

T, som boede i Helsingborg, blev udvist fra Danmark i 2005. 2009 tog han toget fra Malmö til Kastrup for at flyve til Ukraine; i Kastrup blev han anholdt i paskontrollen. Anklagemyndigheden krævede fængsel og mindst 6 års yderligere udvisning (lovens minimum!). Ved byretten samme dag straffet med fængsel i 20 dage og 6 års udvisning. Ved landsrettens dom 41 dage senere nedsattes fængselsstraffen til 10 dage. "Landsretten finder henset til tiltaltes adfærd, at udvisning med indrejseforbud i 6 år vil være uproportionalt." Tiltalte havde været frihedsberøvet under hele sagen. (UfR 2010.314 Ø).

\section{Indførelse af en 'ordensbod'}

Danmark har en meget uhensigtsmæssig bødeordning. Straffelovrådet har tidligere overvejet en ordning, hvorefter mindre bøder skulle være 'sumbøder' og større bøder 'dagbøder'. Meget taler for, at bøder for mindre alvorlige lovovertrædelser kan udmåles takstmæssigt uden hensyntagen til gerningspersonens individuelle, herunder økonomiske forhold, men fortsat med opfyldelse af de almindelige subjektive strafbetingelser (bet. 1424/2002 s. 417 f.); medens større bøder bør fastsættes under fuld hensyntagen til gerningspersonens forhold. (Se især Elholm $2010 \mathrm{~s}$. 
277 ff.). På den baggrund bør det overvejes, om de mindre (sum)bøder, f.eks. under 3000 kr., bør have en anden betegnelse og retlig karakter. Det skal ikke gøres som man argumenterede ved indførelsen af den tyske Ordnungswidrigkeitenrecht (Krümpelmann 1966) - for at skabe Rechtsstaatlichkeit og Kriminalpolitik, men fordi betingelserne bør tilpasses den betydning, indgrebet har for borgeren.

Det kunne efter min opfattelse være naturligt at benævne denne straf 'ordensbod'.

Ændringen i retsgrundlaget bør medføre, at forvandlingsstraffe udelukkes for sådanne ordensbøder. (Den danske brug af forvandlingsstraffe er fortsat et af de mest betændte områder i vor strafferet; den udstilles også af udviklingen i Sverige og Finland).

Man kan så endvidere overveje at anvende 'bødepålæg' i stedet for 'bødeforelæg' for ordensbøderne. Det ville være en administrativ lettelse for politi og anklagemyndighed.

\section{AFSLUTTENDE BEMARKNINGER}

Jørn RT Jacobsen skriver i sin disputats' afsluttende kapitel (2009 s. 608 f.): "Strafferetten i dag pretenderer å uttrykke ein ... moralsk klander, men tenderer samstundes til å ha eit omfang som gjer at den spring langt vidare enn dei tilfella der det kan seiast å ligge føre grunnlag for offentleg moralsk klander, i tillegg til at den har eit represjonsnivå som er vanskeleg å sameine med desse utgangspunkta. Held denne spenninga fram, må ein, sett på spissen, ... gjere eit vegval i denne korsvegen merka med spørsmålet om kva strafferetten skal vere. Skal den til dømes vere ei rein reguleringslovgjeving som konstaterer normbrot og responderer på desse på ein måte som òg kan forsvare eit slikt breitt verkeområde som instituttet synest å få, eller ein meir moralsk ladda institusjon som ber i seg samfunnet sine mest grunnleggande moralske normer og som tildeler klander ved brot på desse, men som dermed òg må avgrensast til tilfelle av klare moralske normbrot, og som må relatere seg til individet som ein moralsk agent deltakande i ein moralsk fellesskap? Strafferetten kan ikkje vere begge desse delane." Dette er en særdeles præcis formulering af dilemmaet.

For en social-, angst- eller politistatsideologi opstår problemet ikke. Hvis det drages frem, sker det på en ganske anden måde, fordi borgeren dér er uden de rettigheder, som er centrale for retstatsideologien. Men for denne er dette et kerneproblem. Skal vi skabe et homogent system for kernestrafferetten? Eller skal vi fastholde det heterogene brede område, som i dag er kriminaliseret, ofte med velfærdstruende sanktioner, som strafferetligt? Dan Frände har utvivlsomt ret i, at "[j]u längre man avlägsnar sig från ... kärnstraffrätt desto mer amoralisk blir straffrätten” (2004 s. 57). Det bliver dermed vanskeligere - måske sågar umuligt - at 
fastholde grundlaget for vore principper. Men er det tilstrækkeligt argument for at give statsmagt og forvaltningsret frie tøjler? Bør man snarere gå den anden vej og sige, at enhver statslig brug af alvorlige sanktioner som led i en disciplinering må forudsætte, at de strafferetlige principper respekteres? For et bekræftende svar på det sidste spørgsmål taler den europæiske menneskeretsdomstols fortolkning af strafbegrebet.

\section{LITTERATUR}

Andrew Ashworth: Principles of Criminal Law, Sixth edition, Oxford 2009.

Petter Asp: Från tanke till gärning, Del I, Legitimationsfrågor rörande förfältsdelikt, Uppsala 2005.

- - - : Från tanke till gärning, Del II, Förberedelse och stämpling till brott, Uppsala 2007.

Karin Cornils: Straffelovens $§ 21-$ Rechtsvergleichende Überlegungen zur Versuchsstrafbarkeit im dänischen Recht; Thomas Elholm et al. (Red.): Ikke kun straf, Festskrift til Vagn Greve, København 2008, s. 89 ff.

Thomas Elholm: 8:13 - om bøder og proportionalitet i specialstrafferetten, København 2010 .

Dan Frände: Allmän straffrätt, 3. uppl., Helsingfors 2004.

Hans Gammeltoft-Hansen: Strafferetspleje III, København 1996.

Vagn Greve: Kriminalitet som normalitet, En studie i den ikke-registrerede kriminalitet i Danmark, København 1972.

- - - : Bør forsæt være en almindelig strafbarhedsbetingelse? Per-Edwin Wallén et al.: Festskrift till Hans Thornstedt, Stockholm 1983, s. $229 \mathrm{ff}$.

- - - : Holdninger i kriminalpolitik og anden politik; Annette Møller-Sørensen \& Anette Storgaard (Red.): Jurist uden omsvøb; Festskrift til Gorm Toftegaard Nielsen, København 2007, s. 165 ff.

Bernard E. Harcourt \& Jens Ludwig: Broken Windows: New Evidence from New York City and a Five-City Social Experiment, The University of Chicago Law Review 2006 s. 271 ff.

C.D.H. [Hedegaard]: Ordqvæder ..., Kiøbenhavn 1776.

Andrew von Hirsch: Fairness, Verbrechen und Strafe: Strafrechtstheoretische Abhandlungen, Berlin 2005.

Lars Holmberg \& Annika Snare: Nul tolerance; Peter Kruize \& Lene Ravn (Red.): Kriminalistisk Årbog 1998 s. 105 ff.

K. Babe Howell: Broken lives from broken windows: the hidden costs of aggressive order-maintenance policing, New York University Review of Law \& Social Change, 2009 s. $271 \mathrm{ff}$. 
Erling Johannes Husabø: Strafansvarets periferi, Medverking, forsøk, førebuing, Bergen 1999.

Douglas Husak: Overcriminalization, The Limits of the Criminal Law, Oxford 2008.

Vilh. Nielsen (Red.): V. Hørup i Skrift og Tale, Udvalgte Artikler og Taler, Andet Bind, København 1903, Tredie Bind, København 1904.

Jørn RT Jacobsen: Fragment til forståing av den rettsstatslege strafferetten, Bergen 2009.

Nils Jareborg: What Kind of Criminal Law Do We Want? On Defensive and Offensive Criminal Law Policy; Annika Snare (Ed.): Scandinavian Studies in Criminology, vol. 14, Oslo 1995, s. 17 ff.; genoptrykt i Nils Jareborg: Scraps of Penal Theory, Uppsala 2002, s. $89 \mathrm{ff}$.

- - - : Kriminalisering som ultima ratio regis?; Eero Backman et al. (Toim.): Pekka Koskiselle 1.1.2003 omistettu, Helsinki 2003, s. 89 ff.; genoptrykt Nils Jareborg: Inkast i straffområdet, Uppsala 2006, s. 29 ff.

Tomislav V. Kovandzic, John J. Sloan, III \& Lynne M. Vieraitis: Unintended consequences of politically popular sentencing policy: the homicide promoting effects of "three strikes" in U.S. cities (1980-1999), Criminology \& Public Policy 2002 s. $399 \mathrm{ff}$.

Justus Krümpelmann: Die Bagatelldelikte, Untersuchungen zum Verbrechen als Steigerungsbegriff, Berlin 1966.

Lars Bo Langsted: Rådgivning II - det strafferetlige medvirkensansvar, København 2007.

Claes Lernestedt: Kriminalisering, Problem och principer, Uppsala 2003.

Alvar Nelson: Billiga brottmål; Torbjörn Andersson (Red.): Festskrift till Per Henrik Lindblom, Uppsala 2004, s. 497 ff.

Friedrich Nowakowski: Nochmals zu $§ 42$ öStGB (Mangelnde Strafwürdigkeit der Tat); Theo Vogler (Hrsg.): Festschrift für Hans-Heinrich Jescheck zum 70. Geburtstag, Zweiter Halbband, Berlin 1985, s. 527 ff.

Heribert Ostendorf: Das Geringfügigkeitsprinzip als strafrechtliches Auslegungsprinzip, Goltdammer's Archiv 1982 s. 333 ff.

Søren Pind: Livet, friheden og ..., blogs.berlingske 13. oktober 2009.

Klaus Priebe: Zur Kodifizierung der "Bagatellkriminalität" in Deutschland und Europa, Eine rechtsvergleichende Studie zur Behandlung eigentums- und vermögensrechtlicher Delikte in Deutschland, der Schweiz, Österreich und der ehemaligen Deutschen Demokratischen Republik, Grasberg bei Bremen 2005.

Per Stangeland \& Ragnar Hauge: Nyanser i grått, En undersøkelse av selvrapportert kriminalitet blant norsk ungdom, Oslo 1974. 
Straffelovrådets betænkning om straffastsættelse og strafferammer I, Almindelig del, nr. 1424, København 2002.

Jørgen Steen Sørensen: Knive og strafudmåling, Skal lovgivningen regulere strafniveauer ned i detaljen, som det er tilfældet i knivsagen? Jyllands-Posten 7. oktober 2009.

- - - : Straffen for besiddelse af knive på offentligt tilgængeligt sted - Højesterets domme af 15. december 2009 (U 2010.789 H og U 2010.796 H), Juristen 2010 s. $58 \mathrm{ff}$.

Three strikes and you're in (for life): an analysis of the California three strikes law as applied to convictions for misdemeanor conduct, Note Thomas Jefferson Law Review 2002 s. 277 ff.

Gorm Toftegaard Nielsen: Strafferet I, Ansvaret, 3. udg., København 2008.

Carl Torp: Bidrag til Læren om Berigelsesforbrydelserne, Kjøbenhavn 1909.

Sergio Vinciguerra: Anmerkungen zur Rechtsgutverletzung und zu Bagatelldelikten im italienischen Recht in der zweiten Hälfte des 20. Jahrhunderts; Ulrich Sieber et al. (Hrsg.): Strafrecht und Wirtschaftsrecht - Dogmatik, Rechtsvergleich, Rechtstatsachen - Festschrift für Klaus Tiedemann zum 70. Geburtstag, München 2008 s. 105 ff.

Uwe Volkmann: Polizeirecht als Sozialtechnologie, Neue Zeitschrift für Verwaltungsrecht 2009, s. $216 \mathrm{ff}$.

Johan Herman Wessel: Hundemordet, Votre Serviteur, Otiosis, 1784.

James Q. Wilson \& George L. Kelling: Broken Windows, The Atlantic Monthly, March 1982.

Adresse:

Nurdugsvej 9,

DK-2670 Greve

vg.ckk@cbs.dk 